(c) American Dairy Science Association, 2006.

\title{
Effect of Automatic Milking Systems on Milk Yield in a Hot Environment
}

\author{
M. Speroni, ${ }^{1}$ G. Pirlo, and S. Lolli ${ }^{2}$ \\ Consiglio per la Ricerca e la Sperimentazione in Agricoltura, Istituto Sperimentale per la Zootecnia, Sezione Operativa di Cremona, \\ I-26100 Cremona, Italy
}

\section{ABSTRACT}

A comparative study was performed to evaluate differences in milk yield between an automatic milking system (AMS) and a conventional herringbone milking parlor system. Two herds of Italian-Friesian cows were reared in the same barn, located in the Po Valley in northern Italy. Twenty-five primiparous cows and 10 multiparous cows were milked with an AMS, while at the same time 29 primiparous and 9 multiparous were milked twice daily in a milking parlor on the other side of the barn. A selection gate allowed cows to access the AMS only if the interval from last milking was $>5 \mathrm{~h}$. Multiparous cows in the AMS yielded more milk than multiparous cows in the milking parlor $(34.2 \pm 0.7 \mathrm{vs}$. $29.4 \pm 0.6 \mathrm{~kg} / \mathrm{d}$ ). There was no difference in milk yield between primiparous cows in the AMS and in the milking parlor ( $28.9 \pm 0.4$ vs. $28.8 \pm 0.3 \mathrm{~kg} / \mathrm{d})$. Milking frequency in the AMS was significantly higher in primiparous $(2.8 \pm 0.03)$ than in multiparous cows $(2.5 \pm 0.04)$. The hot season negatively affected milk yield; the milk yield reduction was higher for cows milked with the AMS $(-4.5 \pm 0.6 \mathrm{~kg} / \mathrm{d})$ than in the milking parlor $(-3.0$ $\pm 0.8 \mathrm{~kg} / \mathrm{d})$. In the AMS, milking frequency decreased during the hot season in primiparous cows $(-0.3 \pm 0.1)$. We concluded that a positive AMS effect on milk yield is possible, but that steps must be taken to alleviate the discomfort involved with attracting cows to the AMS. Key words: automatic milking, dairy cow, milk yield, milking frequency

\section{INTRODUCTION}

A large number of farmers have installed a milking robot for 2 main reasons: 1 ) to improve their quality of life, and 2) to increase the economic efficiency of their farm. They expect to improve milk yield as a consequence of the increase in milking frequency. In automatic milking systems (AMS), the number of milkings per day per cow varies widely depending on the traffic

Received April 1, 2006.

Accepted August 2, 2006.

${ }^{1}$ Corresponding author: marisanna.speroni@isz.it

${ }^{2}$ Current address: Istituto di Zootecnica, Facoltà di Medicina Veterinaria, Università degli Studi di Milano, Via Celoria, 10, 20133Milano, Italy. system (Ketelaar-de Lauwere et al., 2000; Hermans et al., 2003), season (Speroni et al., 2003), stage of lactation (Svennersten-Sjaunja et al., 2000), feeding (Rodenburg and Wheeler, 2002), and distance from the pasture (Spörndly and Wredle, 2004). Although some experiments have resulted in higher milk yields in the AMS than in the traditional systems (Kruip et al., 2002; Wagner-Storch and Palmer, 2003), differences have not been found between the 2 systems in other studies (Hopster et al., 2002). Field studies have yielded different results; Billon and Tournaire (2002) found a reduction in milk yield as a consequence of a reduction in lactation length, whereas Wade et al. (2004) found an increase in milk yield. Moreover, the methodological approach must be taken into account when comparing results from field surveys; Wade et al. (2004) found that when the year effect was not considered, the introduction of an AMS resulted in an increase in milk yield of $12.4 \%$ instead of $2 \%$. In an AMS, the milking interval is variable by cow (de Koning and Ouweltjes, 2000) and season (Speroni et al., 2003); Bach and Busto (2005) found that cows with irregular presentation to the milking station yielded less than cows with constant milking intervals. But the effect of milking interval on milk yield depends on the level of milk yield (Hogeveen et al., 2001). Most of the earlier studies with the AMS were carried out in Northern Europe and did not consider the extreme conditions of Southern Europe, where the summer is hot and humid. Summer in the Po Valley, where most Italian milk is produced, brings high temperatures and humidity; the temperature-humidity index (THI) can exceed critical values for animal welfare in June, July, and August. In cows, as in other domesticated ruminants, thermoregulatory behaviors have been observed (Silanikove, 2000) that reduce locomotion during the hottest hours of the day. In an AMS, this could affect the spontaneity of animal traffic toward the milking station. The objective of this experiment was to compare the AMS with the traditional system in the Po Valley to assess the effects of AMS on milk yield.

\section{MATERIALS AND METHODS}

\section{Animals, Housing, Milking Systems, and Management}

The study was conducted at the Porcellasco Research Farm, in an experimental barn at the CRA-Animal 
Production Research Institute, Cremona, Italy. The barn was a free-stall facility with a central alley that had 2 feeding areas and 2 lying areas on opposite sides; the lying areas were equipped with 2 rows of free stalls. The barn had 2 external paddocks, but cows were not allowed to exit to the external paddocks for most of the winter period because of the risk of slipping.

On one side of the barn, cows were milked twice daily in a conventional $8+8$ herringbone milking parlor (MP), whereas an AMS was used on the other side. The AMS was a commercial single-box robot (VMS; DeLaval, Tumba, Sweden; Abeni et al., 2005). The AMS, with its waiting area, was located between the feeding and resting areas. A preselection gate was installed ahead of the waiting area so that the entrance to the milking area was in the resting area and its exit was in the feeding area; thus, cow traffic in the AMS began in the resting area, went through the milking stall to the feeding area, and then went back to the resting area through one-way gates; only cows with $>5 \mathrm{~h}$ intervals from the last milking were allowed access to the milking station; the others were directed to the feeding area. Cows in the milking parlor were milked at 0530 and $1600 \mathrm{~h}$

The cows in the AMS group were allowed entry to the milking area at any time except during cleaning at 0400,1200 , and $2000 \mathrm{~h}$ for about $30 \mathrm{~min}$ each time, and twice daily (from 0500 to $0600 \mathrm{~h}$ and from 1700 to 1800 $\mathrm{h}$ ), cows were herded to the AMS to avoid milking intervals that were too long.

The experiment was conducted from November 2002 to November 2003. During this period, some cows from the original groups were dried off or culled and others that had just calved were added, so that as a result, 114 different cows were milked. Cows were introduced in a way that ensured that the 2 groups remained comparable for average breeding value, average DIM, and number of primiparous cows. The daily average number of cows milked by the AMS was 38.3 ( $\mathrm{SD}=2.0$ ), of which $22.4(\mathrm{SD}=1.3)$ were heifers $(58.6 \%)$; in the MP the total number of cows was 38.9 ( $\mathrm{SD}=3.2$ ) and there were 25.5 heifers $(\mathrm{SD}=2.8,65.5 \%)$. The reason for the high proportion of primiparous cows in the experimental herds was that we were interested in the effect of the AMS on inexperienced cows.

Only data collected from 14 to 300 DIM were considered for analysis. Data from cows with serious health problems and cows that had $<7$ consecutive milk yield records were eliminated. Thus, 25 primiparous (DIM = $156, \mathrm{SD}=79)$ and 10 multiparous $(\mathrm{DIM}=153, \mathrm{SD}=$ 79) cows were used in the AMS group, whereas the MP group consisted of 29 primiparous $(\mathrm{DIM}=158, \mathrm{SD}=$ 79 ) and 9 multiparous cows $(\mathrm{DIM}=148, \mathrm{SD}=80)$. The multiparous cows had experienced the AMS in their previous lactation.

Both groups were fed the same TMR, consisting of (DM basis) $33.5 \%$ corn silage, 22\% corn grain, 9\% fescue hay, $8 \%$ whole cottonseed, $7.5 \%$ alfalfa hay, $19 \%$ commercial protein concentrate, and $1 \%$ vitamin and mineral premix. The TMR was fed once daily between 0700 and $0800 \mathrm{~h}$. Cows in the AMS also received a concentrate supply in the milking stall: $1 \mathrm{~kg} / \mathrm{d}$ for every $10 \mathrm{~kg}$ of milk yield. This concentrate had an average composition similar to that of the TMR. The MP cows received additional concentrate supplied in the TMR ranging from 0.5 to $1.5 \mathrm{~kg} / \mathrm{d}$; the TMR was provided at the planned DMI level, which allowed a balance in energy and protein intake between the 2 groups.

\section{Data Recording}

Air temperature and relative humidity $(\mathbf{R H})$ were recorded by an automatic station (WST 1800; MTX Italia srl, Modena, Italy) that stored hourly data from 2 sensors located in the middle of the barn between the resting area and the feeding area of each side of the barn. Data were successively downloaded from the data logger to the personal computer via serial connection using special-purpose software (MIDAS Windows; MTX Italia srl). Daily average environmental data from the 2 sides of the barn were not significantly different; thus, the means were used. The THI was calculated as

$$
\begin{aligned}
\mathrm{THI}=\left(1.8 \times{ }^{\circ} \mathrm{T}+32\right)-(0.55-0.55 \times \mathrm{RH} / 100) \\
\left.\times\left[\left(1.8 \times{ }^{\circ} \mathrm{T}+32\right)-58\right)\right],
\end{aligned}
$$

where ${ }^{\circ} \mathrm{T}$ was air temperature, measured as ${ }^{\circ} \mathrm{C}$ (Ingraham et al., 1976). Environmental data were not available from May 28 to June 9 because the sensors were out of order. The air temperature (test_T) and THI (test_THI) values used for statistical analysis were calculated as the average of the actual day on which milk yield was recorded and the 2 preceding days.

Milk yield was recorded weekly as the sum of consecutive milkings in a 24-h interval. In the AMS, information about milking frequency and cow traffic was automatically obtained from the AMS software, for the days on which milk yield was recorded, as the count of events for the $24 \mathrm{~h}$. For each cow, the interval between 2 consecutive milkings was the difference between the 2 milking start times, and the daily average milking interval was analyzed. Cows that presented themselves at the preselection gate $<5 \mathrm{~h}$ after the previous milking were allowed a direct passage from the resting to the feeding area without passing through the milking station; this variable, named the number of presentations without milking (NPWM), was analyzed either sepa- 
rately or together with the milking frequency to obtain the total number of presentations at the preselection gate (TNP); the TNP can be considered a good estimate of the overall attendance at the milking and feeding areas.

\section{Statistical Analysis}

Data were analyzed with the MIXED procedure of SAS (Release 8.02; SAS Institute Inc., Cary, NC). The following mixed model was tested to compare milk yield in the 2 systems:

$$
\begin{gathered}
\mathrm{Y}_{\mathrm{ijklm}}=\mu+\mathrm{MS}_{\mathrm{i}}+\mathrm{Cow}_{\mathrm{ij}}+\mathrm{WIM}_{\mathrm{k}}+\mathrm{S}_{\mathrm{l}}+\mathrm{P}_{\mathrm{m}} \\
+(\mathrm{MS} \times \mathrm{WIM})_{\mathrm{ik}}+(\mathrm{MS} \times \mathrm{S})_{\mathrm{il}}+(\mathrm{MS} \times \mathrm{P})_{\mathrm{im}} \\
+(\mathrm{MS} \times \mathrm{WIM} \times \mathrm{P})_{\mathrm{ikm}}+(\mathrm{MS} \times \mathrm{S} \times \mathrm{P})_{\mathrm{ilm}}+\mathrm{e}_{\mathrm{ijklm}}
\end{gathered}
$$

where $Y_{\mathrm{ijk} k m}$ is the milk yield observed in the ith milking system on cow $\mathrm{j}$, at the kth week in milk, in the lth season and mth parity; $\mu$ is the mean effect, MS is the fixed effect of the milking system ( $i=$ AMS, MP); Cow $_{i j}$ is the random effect associated with the jth cow nested in the ith milking system; WIM is the fixed effect of week in milk ( $k=3$ to 44$) ; \mathrm{S}$ is the fixed season effect ( 1 = before, after); a preliminary graphical analysis of the effect of air temperature and THI on the milk yield pattern enabled us to locate the date from which to consider the start of the hot-season effect. Thus, we stratified milk yield data into 2 classes: before the start of the hot season (from November 26, 2002, to April 29, 2003) and after the start of the hot season (from May 6,2003 , to November 26, 2003); P is the fixed effect of parity $(\mathrm{m}=$ primiparous, multiparous $)$; $(\mathrm{MS} \times \mathrm{WIM})$, $(\mathrm{MS} \times \mathrm{S}),(\mathrm{MS} \times \mathrm{P}),(\mathrm{MS} \times \mathrm{WIM} \times \mathrm{P}),(\mathrm{MS} \times \mathrm{S} \times \mathrm{P})$ are the effects of interactions between fixed factors; and $\mathrm{e}_{\mathrm{ijklm}}$ is the error term. Because more cows were initiated into the study at the beginning of lactation during the cold season than in the hot season, we had a partial confounding between the effect of $\mathrm{S}$ and the effect of WIM; nevertheless, the 2 groups and the 2 levels of parity remained comparable regarding WIM.

A subset considering only the AMS group was used to analyze unique aspects of the AMS:

$$
\begin{aligned}
\mathrm{Y}_{\mathrm{jklm}}= & \mu+\mathrm{Cow}_{\mathrm{jm}}+\mathrm{WIM}_{\mathrm{k}}+\mathrm{S}_{\mathrm{l}}+\mathrm{P}_{\mathrm{m}}+(\mathrm{WIM} \times \mathrm{P})_{\mathrm{km}} \\
& +(\mathrm{S} \times \mathrm{P})_{\mathrm{lm}}+(\mathrm{WIM} \times \mathrm{S} \times \mathrm{P})_{\mathrm{klm}}+\mathrm{e}_{\mathrm{jklm}}
\end{aligned}
$$

where $Y_{j k l m}$ is the milking frequency, milking interval, NPWM, or TNP observed on cow $\mathrm{j}$, by the mth parity, on the kth week in milk, in the lth season; $\mu$ is the mean effect; $\mathrm{Cow}_{\mathrm{ij}}$ is the random effect associated with the jth cow nested in the mth parity; WIM and P are fixed factors, as described above; $\mathrm{S}$ is the fixed effect of season, where lis autumn-winter, spring-summer; and $\mathrm{e}_{\mathrm{ijklm}}$ is the error term.

Also, regression analyses were performed to estimate whether a common slope model would be adequate either

1) for the AMS or MP group to describe the relationship between maximum test_THI and milk yield;

2) for multiparous or primiparous cows to describe the relationship between maximum test_THI and milk yield;

3) for multiparous or primiparous cows in the AMS, to describe the relationship between maximum test_THI and milking frequency, milking interval, NPWM, and TNP; or

4) for primiparous and multiparous cows in the AMS, to describe the relationship between milking interval and hourly milk yield. Hourly milk yield $(\mathrm{kg} / \mathrm{h})$ was calculated by dividing the milk yield for the interval between the start of actual milking and the start of the previous milking.

Milking system or parity fixed factors were introduced into the regression models as covariates and interactions to estimate their effect on the regression slopes.

Diurnal behavioral patterns were studied. The diurnal patterns were created using the percentage of events (milking frequency, NPWM, TNP) performed per hour throughout the experimental period. Percentage data were arcsin transformed prior to statistical analyses. The following mixed model was used to investigate differences in diurnal patterns between hot and cold seasons and between primiparous and multiparous cows:

$$
\begin{gathered}
\mathrm{Y}_{\mathrm{ijlm}}=\mu+\text { Time }_{\mathrm{i}}+\mathrm{Cow}_{\mathrm{im}}+\mathrm{S}_{\mathrm{l}}+\mathrm{P}_{\mathrm{m}}+(\text { Time } \times \mathrm{S})_{\mathrm{il}} \\
+(\text { Time } \times \mathrm{P})_{\mathrm{im}}+\mathrm{e}_{\mathrm{ijlm}}
\end{gathered}
$$

where $Y_{i j l m}$ is the arcsin of the percentage of milking frequency, NPWM, or TNP observed at the ith time for cow $\mathrm{j}$, by the mth parity, in the lth season; $\mu$ is the mean effect; Time is the fixed effect of time of the day ( $\mathrm{i}=0000$ to 2300); $\mathrm{Cow}_{\mathrm{ij}}$ is the random effect associated with the jth cow nested in the mth parity level; $\mathrm{S}$ is the fixed effect of season ( 1 = autumn-winter, springsummer); $\mathrm{P}$ is the fixed effect of parity ( $\mathrm{m}=$ primiparous, multiparous); Time $\times \mathrm{S}$ is the interaction between time and season; Time $\times \mathrm{P}$ is the interaction between time and parity; and $\mathrm{e}_{\mathrm{ijlm}}$ is the error term. 


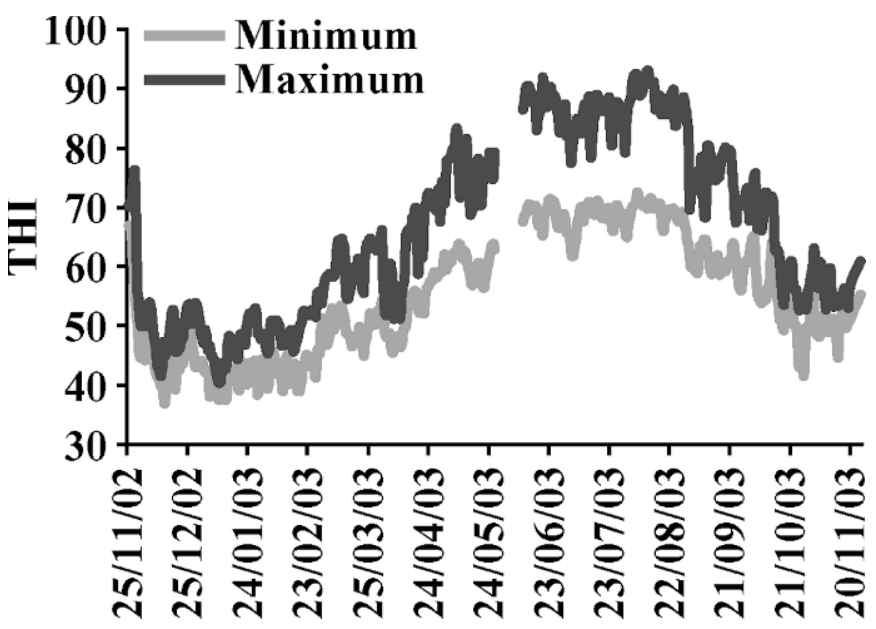

Figure 1. Pattern of minimum and maximum daily temperaturehumidity index (THI) fluctuation throughout the experimental period.

\section{RESULTS}

\section{Environmental Data}

The continuous pattern of THI fluctuation during the experimental period is shown in Figure 1. During 2003 it was particularly hot: the temperature constantly exceeded $25^{\circ} \mathrm{C}$ from the end of April to the end of September, so the THI constantly exceeded 72, and it was above 77 for several days. Although minimum temperatures (nighttime) often fell below $25^{\circ} \mathrm{C}$ and the THI decreased to less than 72 , the minimum temperature exceeded $19^{\circ} \mathrm{C}$ for many days. During the summer, the mean air temperature and THI were $28.0^{\circ} \mathrm{C}(\mathrm{SD}=3.4)$ and 76.5 $(\mathrm{SD}=4.7)$, respectively, during the daytime (0900 to $2000 \mathrm{~h})$ and $23.7(\mathrm{SD}=3.2)$ and $72.2^{\circ} \mathrm{C}(\mathrm{SD}=4.9)$ during the nighttime. These values suggested mild or severe heat stress, with a negative effect on milk yield and DMI.

Overall milk yields were correlated $(\mathrm{r}=-0.60, P<$ 0.001 ) more with the minimum air temperature and minimum test_THI than with the other environmental measures. Maximum THI was the environmental measure correlated with milking frequency $(\mathrm{r}=-0.59 ; P<$ $0.001)$, milking interval $(\mathrm{r}=0.59 ; P<0.001)$, NPWM $(\mathrm{r}=-0.64 ; P<0.001)$, and TNP $(\mathrm{r}=-0.62 ; P<0.001)$; therefore, the maximum THI was used to test the regression effect of the hot season on cow performance.

\section{Milk Yield}

Milk yield was affected by the milking system $(P<$ $0.001)$, week in milk $(P<0.001)$, season $(P<0.001)$, parity $(P<0.001)$, parity $\times$ milking system interaction $(P<0.001)$, week in milk $\times$ milking system $\times$ parity interaction $(P<0.05)$, and season $\times$ milking system $\times$ parity interaction $(P<0.005)$. Cows in the AMS group yielded $2.4 \pm 0.6 \mathrm{~kg} / \mathrm{d}$ more than cows in the MP group. Milk yield was higher during the cold season than the hot season ( $32.2 \pm 0.4$ vs. $28.8 \pm 0.3 \mathrm{~kg} / \mathrm{d})$. Multiparous cows yielded $3.0 \pm 0.5 \mathrm{~kg} / \mathrm{d}$ more than primiparous cows. Multiparous cows in the AMS group yielded more than the MP multiparous cows. There was no difference in milk yield between primiparous cows milked by the AMS or MP (Table 1). Milk yield significantly decreased by $4.5 \pm 0.6$ and $3.0 \pm 0.8 \mathrm{~kg} / \mathrm{d}$ in the AMS and MP groups, respectively, from the cold to the hot season, so that the difference between the AMS and MP was $3.21 \pm 0.88 \mathrm{~kg} / \mathrm{d}(P<0.001)$ during the cold season, whereas it was only $1.67 \pm 0.60 \mathrm{~kg} / \mathrm{d}(P<0.01)$ during the hot season.

The regression slope curve between milk yield and maximum test_THI was higher for the AMS cows $(+0.10$ $\pm 0.02 \mathrm{~kg} / \mathrm{d}$ per THI; $P<0.001)$ than the MP cows and for multiparous cows $(+0.07 \pm 0.03 \mathrm{~kg} / \mathrm{d}$ per THI; $P=$ 0.0036 ) than for primiparous cows.

\section{Milking Frequency, Milking Interval, and Hourly Milk Yield in the AMS}

The ANOVA for milking frequency and milking interval revealed significant season $(P<0.005$ and $P<0.001$, respectively) and parity $(P<0.001$ and $P<0.005$, respectively) effects. Milking frequency was higher during autumn-winter than during spring-summer $(2.7 \pm 0.04$ vs. $2.6 \pm 0.03)$ and higher in primiparous $(2.8 \pm 0.03)$ than in multiparous $(2.5 \pm 0.04)$ cows; the difference in milking frequency between the cold and hot seasons was significantly different $(P<0.001)$ from 0 only in primiparous cows $(-0.3 \pm 0.1)$. The milking interval was lower during autumn-winter ( $8 \mathrm{~h} 51 \mathrm{~min} \pm 11 \mathrm{~min})$ than during spring-summer ( $9 \mathrm{~h} 38 \mathrm{~min} \pm 9 \mathrm{~min})$, and it was lower in primiparous ( $8 \mathrm{~h} 46 \mathrm{~min} \pm 9 \mathrm{~min}$ ) than in multiparous cows (9 h $43 \mathrm{~min} \pm 15 \mathrm{~min}$ ). The regression slope between milk yield and milking interval was the same for multiparous and primiparous cows either in the autumn-winter or in the spring-summer season.

\section{Activity Measures}

The ANOVA for NPWM and TPN revealed significant season $(P<0.001)$ and parity $(P<0.001)$ effects and significant season $\times$ parity interactions $(P<0.05)$. During the autumn-winter season, cows had $2.2 \pm 0.1$ NPWM and $4.9 \pm 0.2 \mathrm{TPN}$, whereas during the springsummer season, they had $2.7 \pm 0.2 \mathrm{NPWM}$ and $4.1 \pm$ 0.2 TPN. Primiparous cows had $3.2 \pm 0.1 \mathrm{NPWM}$ and $5.3 \pm 0.1 \mathrm{TPN}$; they had $3.6 \pm 0.1$ and $2.8 \pm 0.1 \mathrm{NPWM}$ and $5.9 \pm 0.2$ and $4.8 \pm 0.2 \mathrm{TPN}$ in the autumn-winter 
Table 1. Least squares means $( \pm \mathrm{SEM})$ of milk yield $(\mathrm{kg} / \mathrm{d})$ in primiparous and multiparous cows before and after the start of the hot season ${ }^{1}$

\begin{tabular}{lllllllll}
\hline & \multicolumn{3}{c}{ Primiparous } & & \multicolumn{3}{c}{ Multiparous } & \\
\cline { 2 - 4 } \cline { 6 - 7 } Item & Before & After & Total & & Before & After & Total & Total \\
\hline AMS & $31.6 \pm 0.6^{*}$ & $26.2 \pm 0.4$ & $28.9 \pm 0.4$ & & $36.0 \pm 1.0^{*}$ & $32.3 \pm 0.6$ & $34.2 \pm 0.7$ & $31.5 \pm 0.4$ \\
MP & $29.2 \pm 0.5$ & $28.3 \pm 0.4$ & $28.8 \pm 0.3$ & & $31.9 \pm 1.1^{*}$ & $26.9 \pm 0.6$ & $29.4 \pm 0.6$ & $29.1 \pm 0.4$ \\
$P$ & $<0.005$ & $<0.001$ & NS & $<0.01$ & $<0.001$ & $<0.001$ & $<0.001$ \\
\hline
\end{tabular}

${ }^{1} \mathrm{AMS}=$ Automatic milking system; MP = milking parlor system; Before $=$ before the start of the hot period; After $=$ after the start of the hot period; $\mathrm{P}=$ probability of a greater $t$-value for the differences between means in columns.

*Asterisks associated with means in a row indicate a difference $(P<0.001)$ between before and after the start of the hot season within parity and within milking system.

and spring-summer seasons, respectively. Multiparous cows were less active than primiparous cows and their activities $(1.8 \pm 0.2 \mathrm{NPWM}, 3.7 \pm 0.2 \mathrm{TPN})$ did not differ by season; the effect of season on primiparous cows was confirmed by the slope of the regression between TNP and maximum THI, which was higher $(P=0.005)$ for the primiparous cows than for the multiparous cows.

\section{Diurnal Activity Patterns}

The diurnal pattern of milking frequency did not differ between cold and warm seasons, whereas differences were found in the NPWM pattern by season $(P$ $<0.001)$ and by parity $(P=0.01)$. Figure 2 shows the diurnal pattern of NPWM for primiparous cows. Peaks corresponded to fetching time, with most of the passages occurring in the daytime; activity decreased at night (from 2200 to $0400 \mathrm{~h}$ ) more during the hot season than during the cold season.

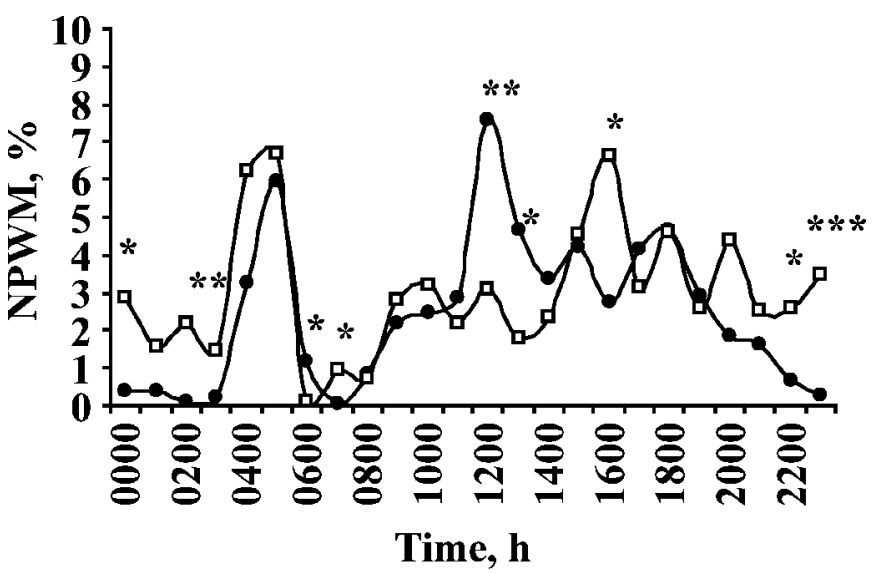

Figure 2. Diurnal pattern of percentage (back-transformed least squares means) of presentations without milking (NPWM) during the autumn-winter $(\square)$ or spring-summer $(\bullet)$ periods for primiparous cows. Asterisks indicate significant differences between periods $\left(* P<0.05,{ }^{*} P<0.01\right.$, and $\left.* * * P<0.001\right)$.

\section{DISCUSSION}

Automatic milking systems were expected to improve milk yield as a consequence of increased milking frequency. When AMS started to be used in Europe, a 10 to $15 \%$ higher milk yield per cow was assumed to be possible compared with traditional twice-daily milking (Schön et al., 1992; Hogeveen et al., 2001). This forecast was based on results obtained when farms made the transition from 2 to 3 milkings per day. Actually, planned experiments and surveys in commercial farms comparing AMS with conventional systems gave a variety of results.

Our results indicate that an increase in milk yield with the AMS is possible, but parity and environmental conditions can influence this result. Cows in the AMS yielded more milk than cows in the MP, but the increased milk yield was observed only in multiparous cows, although they had a lower milking frequency. The difference observed between primiparous and multiparous cows can be explained by 2 hypotheses. First, it could be argued that multiparous cows are more likely to gain an advantage when milked in the AMS. In a herd milked by the AMS, the effect of milking interval on milk yield depends on the ratio between the positive effect on cows milked 3 or more times daily and the negative effect on cows milked less than twice daily. Therefore, multiparous cows are more likely to have an advantage when milked in the AMS because, as Hogeveen et al. (2001) reported, short milking intervals have a larger effect on the increase in hourly milk production in higher producing cows than in lower producing cows milked in the AMS; also, multiparous cows, which have a larger cistern capacity (Dewhurst and Knight, 1993), may have a less negative effect on milk yield from an extended milking interval than primiparous cows (Ayadi et al., 2003). We were unable to show a different positive effect of reduced milking interval because the regression curves between milking intervals and hourly milk yield had the same slope for multiparous and primiparous cows. 
The second and most acceptable hypothesis is that primiparous cows had difficulty in acclimating to the AMS and were more stressed than multiparous cows during the milking procedure. Moreover, the multiparous cows tested in the current trial had experienced the AMS in their previous lactation. Weiss et al. (2005) showed that experienced cows produced more than inexperienced cows during the first 15 milkings in the AMS as compared with previous parlor yields. The difference between primiparous and multiparous cows may also be related to different learning ability and memory characteristics. Kovalčik and Kovalčik (1986) showed lower learning ability in primiparous cows than in multiparous cows. In our experiment, primiparous cows produced less than multiparous cows, although they had a higher milking frequency than multiparous cows. Hayashi and Kawamura (2002) found yields per milking lower in primiparous than in multiparous cows. Our results are consistent with those of Spolders et al. (2004), who found that primiparous cows visited the AMS more than did multiparous cows. The lack of increase in milk yield as a consequence of the high milking frequency in primiparous cows allows us to state that high milking frequency is not a sufficient condition for increasing the milk yield with the AMS.

In our experiment, values for the air temperature and THI, if related to the critical values suggested by Armstrong (1994), indicate conditions for mild to severe heat stress. The minimum THI and minimum air temperature were correlated with the DMI (Holter et al., 1997) and milk yield (Ravagnolo et al., 2000). Usually cows cope with heat stress by eating more feed at night than during the day, but if the temperature also remains high during the night, they cannot compensate. This is the case when the minimum environmental temperature exceeds $19^{\circ} \mathrm{C}$, as in our experiment. During the hot season, the primiparous cows in the AMS group reduced nocturnal attendance at the milking area more than in the cold season; this resulted in a decrease in the number of visits to the feeding area and probably in the number of meals. Reducing activity to contain heat production was probably a bigger problem for the AMS group, for which the voluntary move to the milking area was necessary to maintain an appropriate milking frequency and adequate attendance at the feeding area. In the AMS group, primiparous cows had a larger reduction of activity than multiparous cows.

\section{CONCLUSIONS}

We concluded that an AMS effect on milk yield is possible, but steps must be taken to alleviate discomfort and to attract cows to the AMS during hot seasons. Candidate approaches are to have optimal locations for cooling systems, self-feeders, and water troughs. Particular attention must be paid to the management of primiparous cows.

\section{ACKNOWLEDGMENT}

This experiment is part of the Project "Total Automation of the Dairy Barn" funded by the Italian Ministry of Agriculture and Forestry Policy.

\section{REFERENCES}

Abeni, F., L. Calamari, F. Calza, M. Speroni, G. Bertoni, and G. Pirlo. 2005. Welfare assessment based on metabolic and endocrine aspects in primiparous cows milked in a parlor or with an automatic milking system. J. Dairy Sci. 88:3542-3552.

Armstrong, D. V. 1994. Heat stress interaction with shade and cooling. J. Dairy Sci. 77:2044-2050.

Ayadi, M., G. Caja, X. Such, and C. H. Knight. 2003. Effect of omitting one milking weekly on lactational performances and morphological udder changes in dairy cows. J. Dairy Sci. 86:2352-2358.

Bach, A., and I. Busto. 2005. Effects on milk yield of milking interval regularity and teat cup attachment failures with robotic milking systems. J. Dairy Res. 72:101-106.

Billon, P., and F. Tournaire. 2002. Impact of automatic milking systems on milk quality and farm management: The French experience. Pages V59-V63 in The First North American Conference on Robotic Milking, Proc., Toronto, Canada. Wageningen Pers, Wageningen, The Netherlands.

de Koning, C. J. A. M., and W. Ouweltjes. 2000. Maximising the milking capacity of an automatic milking system. Pages 38-46 in Int. Symp. on Robotic Milking. H. Hogeveen and A. Meijring, ed. Wageningen Pers, Wageningen, The Netherlands.

Dewhurst, R. J., and C. H. Knight. 1993. An investigation of the changes in sites of milk storage in the bovine udder over two lactation cycles. Anim. Prod. 57:379-384.

Hayashi, T., and T. Kawamura. 2002. Effect of an automatic milking system on milking traits. Anim. Sci. J. 73:403-408.

Hermans, G. G. N., A. H. Ipema, J. Stefanowska, and J. H. M. Metz. 2003. The effect of two traffic situations on the behavior and performance of cows in an automatic milking system. J. Dairy Sci. 86:1997-2004.

Hogeveen, H., W. Ouweltjes, C. J. A. M. de Koning, and K. Stelwagen. 2001. Milking interval, milk production and milk flow-rate in an automatic milking system. Livest. Prod. Sci. 72:157-167.

Holter, J. B., J. W. West, and M. L. McGilliard. 1997. Predicting ad libitum dry matter intake and yield of Holstein cows. J. Dairy Sci. 80:2188-2199.

Hopster, H., R. M. Bruckmaier, J. T. N. var der Werf, S. M. Korte, J. Macuhova, G. Korte-Bouws, and C. G. van Reenen. 2002. Stress responses during milking: Comparing conventional and automatic milking in primiparous dairy cows. J. Dairy Sci. 85:3206-3216.

Ingraham, R. H., R. W. Stanley, and W. C. Wagner. 1976. Relationship of temperature and humidity to conception rate of Holstein cows in Hawaii. J. Dairy Sci. 59:2086-2090.

Ketelaar-de Lauwere, C. C., M. M. W. B. Hendriks, J. Zondag, A. H. Ipema, J. H. M. Metz, and J. P. T. M. Noordhuizen. 2000. Influence of routing treatments on cows' visit to an automatic milking system, their time budget and other behaviour. Acta Agric. Scand., A Anim. Sci. 50:174-183.

Kovalčik, K., and M. Kovalčik. 1986. Learning ability and memory testing in cattle of different ages. Appl. Anim. Behav. Sci. 15:27-29.

Kruip, T. A. M., H. Morice, M. Robert, and W. Ouweltjes. 2002. Robotic milking and its effect on fertility and cell counts. J. Dairy Sci. 85:2576-2581. 
Ravagnolo, O., I. Misztal, and G. Hoogenboom. 2000. Genetic component of heat stress in dairy cattle, development of heat index function. J. Dairy Sci. 83:2120-2125.

Rodenburg, J., and B. Wheeler. 2002. Strategies for incorporating robotic milking into North American herd management. Pages III18-III32 in The First North American Conference on Robotic Milking, Proc., Toronto, Canada. Wageningen Pers, Wageningen, The Netherlands.

Schön, H., R. Artmann, and H. Worstorff. 1992. The automation of milking as a key issue in future oriented dairy farming. Pages 7-22 in Proc. International Symp.: Prospects for Automatic Milking. A. H. Ipema, A. C. Lippus, J. H. M. Metz, and W. Rossing, ed. EAAP Publ. No. 65. Pudoc, Wageningen, The Netherlands

Silanikove, N. 2000. Effects of heat stress on the welfare of extensively managed domestic ruminants. Livest. Prod. Sci. 67:1-18.

Speroni, M., F. Abeni, M. Capelletti, L. Migliorati, and G. Pirlo. 2003. Two years of experience with an automatic milking system. 2 . Milk yield, milk interval and frequency. Ital. J. Anim. Sci. 2(Suppl. 1):260-262.

Spolders, M., U. Meyer, G. Flachowsky, and M. Coenen. 2004. Differences between primiparous and multiparous cows in voluntary milking frequency in an automatic milking system. Ital. J. Anim. Sci. 3:167-175.
Spörndly, E., and E. Wredle. 2004. Automatic milking and grazingeffects of distance to pasture and level of supplements on milk yield and cow behavior. J. Dairy Sci. 87:1702-1712.

Svennersten-Sjaunja, K., I. Berglund, and G. Pettersson. 2000. The milking process in an automatic milking system, evaluation of milk yield, teat condition and udder health. Pages 277-288 in Robotic Milking. Proc. Int. Symp., Lelystad, The Netherlands. H. Hogeveen and A. Meijering, ed. Wageningen Pers, Wageningen, The Netherlands.

Wade, K. M., M. A. P. M. van Asseldonk, P. B. M. Berenstsen, W. Ouweltjes, and H. Hogeveen. 2004. Economic efficiency of automatic milking systems with specific emphasis on increases in milk production. Pages 62-67 in Automatic Milking, a Better Understanding. A. Meijering, H. Hogeveen, and C. J. A. M. de Koning, ed. Wageningen Academic Publishers, Wageningen, The Netherlands.

Wagner-Storch, A. M., and R. W. Palmer. 2003. Feeding behavior, milking behavior, and milk yields of cows milked in a parlor versus an automatic milking system. J. Dairy Sci. 86:1494-1502.

Weiss, D., E. Moestl, and R. M. Bruckmaier. 2005. Phyisiological and behavioural effects of changeover from conventional to automatic milking in dairy cows with and without previous experience. Vet. Med. Czech. 50: 253-261. 